\title{
Heavy metal pollution assessment in the groundwater of the Meghna Ghat industrial area, Bangladesh, by using water pollution indices approach
}

\author{
Mirza A. T. M. Tanvir Rahman ${ }^{1,3}$ (1) Moutushi Paul ${ }^{1} \cdot$ Nikhil Bhoumik $^{2} \cdot$ Mahmud Hassan $^{1} \cdot$ Md. Khorshed Alam $^{3}$. \\ Zakia Aktar ${ }^{3}$
}

Received: 20 November 2017 / Accepted: 18 June 2020 / Published online: 9 July 2020

(c) The Author(s) 2020

\begin{abstract}
Heavy metal pollution in groundwater is a substantial environmental risk for Bangladesh. The Meghna Ghat industrial area in Bangladesh becomes a promising site for installing various industries for few decades. It was necessary to assess the heavy metal level in the groundwater of this area, and current study took the initiative. We collected 20 groundwater samples and tested $\mathrm{pH}, \mathrm{DO}, \mathrm{TDS}, \mathrm{EC}$, turbidity, $\mathrm{COD}$, and $\mathrm{DOC}$ as well as four heavy metals $(\mathrm{Cr}, \mathrm{Cd}, \mathrm{Pb}$, and $\mathrm{Ni})$ to calculate four water quality indices, i.e., water quality index (WQI), degree of contamination (DC), heavy metal evaluation index (HEI), and heavy metal pollution index (HPI). Ni was too low to detect by the instrument, whereas the mean concentrations of $\mathrm{Cr}, \mathrm{Cd}$, and $\mathrm{Pb}$ were $0.07,0.007$, and $0.18 \mathrm{mg} / \mathrm{L}$ which exceeded the drinking water standards set by Bangladesh. According to the water quality indices, only $10 \%$ samples were good according to WQI; $30 \%$ and $15 \%$ samples were subjected to low level of pollution considering DC and HEI, respectively. Although according to HPI 35\% samples were unsuitable for drinking, rest of the values were very close to characterize as unsuitable. Finally, we proposed two best-fitted models that can represent relationships between the metals and water quality indices. Water quality was comparatively better near the open spaces of the study area. The area needed to be under continuous monitoring for checking further pollution distribution.
\end{abstract}

Keywords Cadmium $\cdot$ Chromium $\cdot$ Degree of contamination $\cdot$ Heavy metal evaluation index $\cdot$ Heavy metal pollution index $\cdot$ Lead $\cdot$ Water quality index

\section{Introduction}

Industrial development helps humans' life easy due to enormous scientific and technological progresses. However, global development raises new challenges in the field of environmental protection and conservation (Bennett et al. 2003), and the development activities are often linked to polluting the environment (Ikhuoria and Okieimen 2000). Industrial pollution has a negative impact on the

Mirza A. T. M. Tanvir Rahman

tanvir497@juniv.edu

1 Department of Environmental Sciences, Jahangirnagar University, Savar, Dhaka 1342, Bangladesh

2 Wazed Miah Science Research Center, Jahangirnagar University, Savar, Dhaka 1342, Bangladesh

3 Graduate School of Environmental Science, Hokkaido University, Sapporo, Hokkaido 060-0810, Japan environment that even leads to an irreversible effect on the nature, and as a result, the concentrations of heavy metals are increasing in the waterways (Singh et al. 2011) where the industrial wastewater is discharging many of the hazardous chemical elements that may accumulate in the soil and sediments of the water bodies (Begum et al. 2009).

There are over 50 elements that can be categorized as heavy metals, and 17 of those are recognized to be very toxic and relatively accessible (Singh et al. 2011). According to Nriagu (1992), about $90 \%$ of the anthropogenic emissions of heavy metals have occurred since 1900 AD. These toxic substances are releasing into the environment causing a variety of toxic effects on the living organisms (Dembitsky 2003). However, many of the heavy metals are required by the body in minute amounts but can be toxic in large doses (Singh et al. 2011). The known fatal impacts arising from heavy metal toxicity include damaging or reducing mental and central nervous functions as well as causing irregularity 
in blood composition that can badly affect vital organs such as kidneys and liver (Khan et al. 2011).

Many of the heavy metals such as lead (Pb), chromium $(\mathrm{Cr})$, cadmium $(\mathrm{Cd})$, and nickel $(\mathrm{Ni})$ are useful for various industrial activities. For example, in 2012 worldwide about 10.54 million tons of $\mathrm{Pb}$ has been produced of which $85.1 \%$ uses in batteries, $5.5 \%$ in pigments, $3.6 \%$ in rolled and extruded products, $1.4 \%$ in ammunition, $1.3 \%$ in alloys, $0.9 \%$ in cable sheathing, and rest $2.1 \%$ in miscellaneous (ILA 2017). Tetraethyl and tetramethyl $\mathrm{Pb}$ are important because of their extensive use as antiknock compounds in petrol (Quinn and Sherlock 1990). In industries, Cr is used for producing steel, electroplating, pigment and dye, wood preservation, tanning, foundry, for processing hydrocarbons as catalyst, etc. (Lunk 2015). Cadmium and Ni are largely used in batteries and metal electroplating industries (Panakkal and Kumar 2014).

Industrialization in Bangladesh leads to surface water and groundwater pollution in many parts of the country. The water-polluted areas in Bangladesh are mostly located in the highly industrialized area. The Meghna Ghat industrial area in Narayanganj, Bangladesh, locating near the capital city is blooming as an economic zone very quickly and so possesses a threat to pollute the groundwater. It is located in an island in the Meghna river that has an area of $4.5 \mathrm{~km}^{2}$. Groundwater ion concentrations for sodium, calcium, chloride, and sulfate in nearby area were $60,43,85$, and $4 \mathrm{mg} / \mathrm{L}$, respectively, which were less than highly geologically influenced groundwater in the southwestern zone of Bangladesh with values of $222.96,62.8,409.6$, and $11.79 \mathrm{mg} / \mathrm{L}$, respectively (Islam et al. 2015; Rahman et al. 2011). There are few studies on heavy metal pollution of the Meghna river (e.g., Hassan et al. 2015; Haque 2018) as well as limited studies on groundwater of the surrounding area. For example, in 1998 in the shallow groundwater of the nearby area, chromium concentration was $<0.02 \mathrm{mg} / \mathrm{L}$ (well depth $=41 \mathrm{~m}$; BGS and DPHE 2001), and in 2004 chromium, cadmium, and lead concentrations were $0.01-0.03,0.002-0.03$, and $0.09-0.38 \mathrm{mg} / \mathrm{L}$, respectively (well depth $=20-66 \mathrm{~m}$; Seddique et al. 2004). Therefore, it was needed to examine the current pollution status in the Meghna Ghat industrial area.

Water quality of any specific area or specific source can be assessed using physical, chemical, and biological parameters (Tyagi et al. 2013). Nowadays, it is a common practice to use the water quality index rather than using single or several water parameters and many workers study to develop applicable indices for managing water quality (e.g., Backman et al. 1998; Batabyal and Chakraborty 2015; Bhargava et al. 1998; Bhuiyan et al. 2010; Chen et al. 2019; Das Kangabam et al. 2017; Dwivedi et al. 1997; Gao et al. 2020; Mohan et al. 1996; Molekoa et al. 2019; Nath et al. 2018; Tandel et al. 2011; Vasanthavigar et al. 2010; Wu et al. 2017). The advantage of such approach is the possibility to incorporate various parameters into the calculation that can provide an integrated scenario of the examined water. Such index combines several parameters to provide a single unitless value that reflects overall condition of the targeted water body (Abtahi et al. 2015; Wu et al. 2017). This information is very helpful for the water managers who need compact data in a simpler form to analysis and demonstrate to other stakeholders in an easy way for better understanding. Another important advantage of using such index is the universal comparability with other water bodies of the world.

We carried out this study as a preliminary survey on heavy metal pollution in groundwater of the Meghna Ghat industrial area. Since metals are not degradable and can accumulate in the human body system, monitoring is required on an ongoing basis due to the increasing concentration of heavy metals in potable water that increases the threat to human health and the environment (Herojeet et al. 2015). It is anticipated that this study would provide a baseline data regarding the distribution of the selected metals in groundwater. We used water quality determining indices besides using single parameters to assess the water quality. We determined four water quality indices, i.e., water quality index (WQI), degree of contamination (DC), heavy metal evaluation index (HEI) and heavy metal pollution index (HPI). We used the indices to access the overall quality of groundwater in the studied industrial area and to identify the most and least polluted parts of the area.

\section{Materials and methods}

\section{Study area and sample collection}

We collected twenty groundwater samples from the industrial area of the Meghna Ghat, Narayanganj City, that situated on the bank of the Meghna river in Bangladesh (Fig. 1). The area is under the fluvial floodplains of the Ganges, Brahmaputra, Tista, and Meghna rivers (Morgan and McIntire 1959) with the lithology of clay to medium sand (Fig. 1c) (BGS and DPHE 2001). The study area experiences the tropical climate. The closest weather station in Dhaka (the capital city) recorded the mean daily maximum and minimum temperature as of $40^{\circ} \mathrm{C}$ (August) and $5{ }^{\circ} \mathrm{C}$ (January), respectively, for a period of 2007 to 2015 with an annual rainfall of about $2347 \mathrm{~mm}$ in 2001-2015 (BMD 2020). The Meghna Ghat industrial area is one of the rapid blooming economic zones that already have industries on pulp and paper, tissue paper, sanitary napkin, baby diaper, PVC plant, oil refinery, flour mill, power plant, salt, chemical, sugar processing, shipyard, cement, steel, etc. Part of the Meghna Ghat industrial area was declared as a privately owned economic zone named as the Meghna Economic Zone (MEZ) in 2016, and in future, the area will be more industrialized and expected 

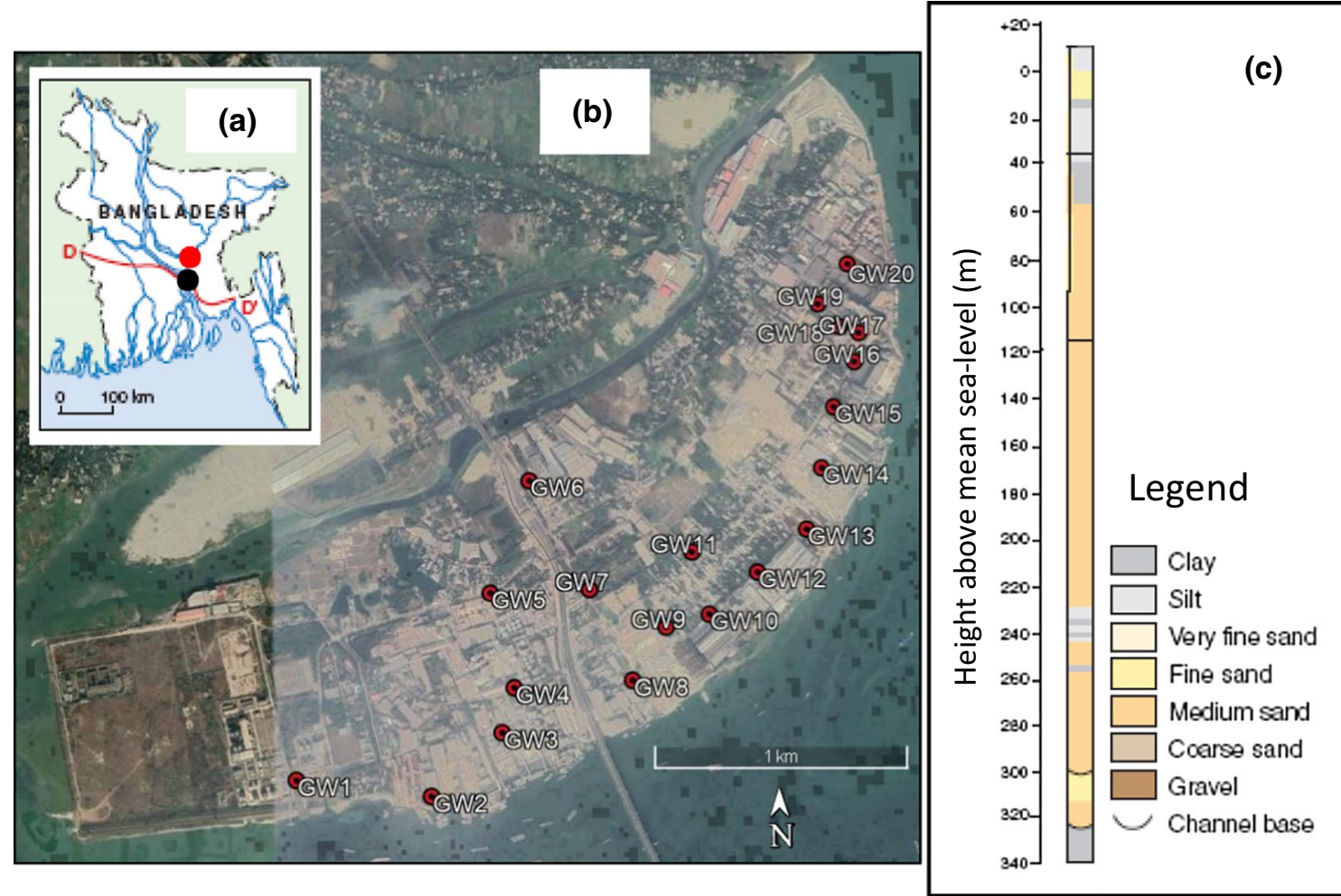

Fig. 1 The study area map of the Meghna Ghat industrial area. Bangladesh map showing location of the study area as red circle and location of bore hole as black circle (a), sampling locations show-

to create more than twenty thousand jobs (BEZA 2017). Most of the industries were located in the north, south, and east sides, and open area was located in the southwestern, central part as well as some sporadic parts of the study area.

The samples were collected in August 2015 from shallow tube well (depth $<200 \mathrm{ft}$ ). Sampling locations were recorded using handheld GPS receiver (eXplorist 200). The water samples collected in polyethylene bottles which were prewashed with $20 \%$ nitric acid and double-distilled water. For measuring heavy metal concentration, $65 \%$ concentrated $\mathrm{HNO}_{3}$ acid was added to each sample immediately after the collection to bring the $\mathrm{pH}$ below 2 to minimize precipitation and adsorption onto container walls (APHA 1998).

\section{Physicochemical parameters}

In the sampling sites we measured $\mathrm{pH}$, dissolved oxygen (DO), total dissolved solids (TDS), electrical conductivity (EC) and turbidity by using portable $\mathrm{pH}$ meter (Ecoscen Model 1161795), DO meter (Ecoscen DO 110), TDS meter (HANNA HI 8734), EC meter (HANNA HI 8033) and turbidity meter (HANNA 93703), respectively. The closed reflux colorimetric method was used to measure chemical oxygen demand (COD) using HACH supplied reagents and COD reactor (HACH DRB200) according to the manual. ing with sampling IDs (map was produced by the Google Earth Pro7.3.3.7699) (b), and lithology of bore hole which was adopted from BGS and DPHE (2001) (c)

Dissolved organic carbon (DOC) was measured by total organic carbon (TOC) analyzer (SHIMADZU) according to APHA (1998).

For metal analysis, we digested the water samples with concentrated $\mathrm{HNO}_{3}$ acid (APHA 1998) in the laboratory of the Department of Environmental Sciences, Jahangirnagar University, Bangladesh. After the digestion, we sent the samples to determine $\mathrm{Cr}, \mathrm{Cd}, \mathrm{Pb}$, and $\mathrm{Ni}$ concentrations to the laboratory of the Wazed Miah Science Research Center, Bangladesh.

\section{Groundwater pollution analyses}

We used four indices to evaluate the water quality in the studied area which were water quality index (WQI), degree of contamination (DC), heavy metal evaluation index (HEI), and heavy metal pollution index (HPI). Water quality index was calculated by taking consideration of all physicochemical parameters, whereas other three indices considered only the metal concentrations.

\section{Water quality index}

Water quality index was first proposed by Horton (1965). Generally, WQI is discussed for a particular and intended 
use of water (Etim et al. 2012). In this study, we considered WQI for human consumption. It was calculated in three main steps, i.e., selection of parameters, determination of sub-indices, and finally sub-indices aggregation with mathematical expression (Fernández et al. 2004). We calculated WQI according to Tandel et al. (2011) which was done by using the weighted arithmetic index method. The quality rating scale for each parameter, $Q_{i}$, was calculated by using the following expression:

$Q_{i}=100\left[\left(V_{n}-V_{\mathrm{i}}\right) /\left(V_{\mathrm{s}}-V_{\mathrm{i}}\right)\right]$

where $V_{n}=$ the actual amount of $n$th parameter and $V_{\mathrm{i}}=$ the ideal value of this parameter. $V_{\mathrm{i}}=0$, except for $\mathrm{pH}\left(V_{\mathrm{i}}=7.0\right)$ and $\mathrm{DO}\left(V_{\mathrm{i}}=14.6 \mathrm{mg} / \mathrm{L}\right) . V_{\mathrm{s}}$ is the recommended standard of the corresponding parameter. Here, we considered the standard values of all parameters taking from the Department of Environment of Bangladesh (DoE 1997) except the standard value of EC. Because DoE (1997) did not establish standard for EC, we considered FAO (1972) standard.

Relative weight $\left(W_{i}\right)$ was calculated by a value inversely equal to the recommended standard $\left(S_{i}\right)$ of the corresponding parameter as:

$W_{i}=1 / S_{i}$

Finally, overall WQI was calculated by using the following equation:

$\mathrm{WQI}=\Sigma W_{i} Q_{i} / \Sigma W_{i}$

\section{Degree of contamination}

Degree of contamination summarized the combined effects of several quality parameters regarded as harmful to household water (Backman et al. 1998). We calculated it as the following equation:

$\mathrm{DC}=\sum_{i=1}^{n} C_{\mathrm{fi}}$

where $C_{\mathrm{fi}}=\frac{C_{\mathrm{Ai}}}{C_{\mathrm{Ni}}}-1 ; C_{\mathrm{fi}}=$ contamination factor; $C_{\mathrm{Ai}}=$ analytical value and $C_{\mathrm{Ni}}=$ upper permissible concentration of the $i$ th parameter, and $N=$ normative value. Here, $C_{\mathrm{Ni}}$ was taken as DoE (1997) standard of the $i$ th parameter.

\section{Heavy metal evaluation index}

Heavy metal evaluation index provided an overall quality of water for heavy metals (Edet and Offiong 2002) and had been calculated as follows:
$\mathrm{HEI}=\sum_{i=1}^{n} \frac{H_{c}}{H_{\mathrm{MAC}}}$

where $H_{c}=$ the monitored value and $H_{\mathrm{MAC}}=$ the maximum admissible concentration (MAC) of the $i$ th parameter.

\section{Heavy metal pollution index}

Heavy metal pollution index was based on the weighted arithmetic mean method which was developed on two basic steps-establishing of a rating scale for each selected quality characteristic giving weight to the selected parameter and selecting of pollution parameters on which the index was to be based on (Mohan et al. 1996). Rating scale (system) or unit weight $\left(W_{\mathrm{i}}\right)$ was an arbitrary value (between zero and one, when metal concentration unit was ppb) that determined as the inverse of maximum admissible concentration (MAC). MAC values of $\mathrm{Cr}, \mathrm{Cd}, \mathrm{Pb}$, and $\mathrm{Ni}$ were $0.05,0.003,0.0015$, and $0.02 \mathrm{mg} / \mathrm{L}$, respectively (adapted from Siegel 2002). We determined HPI according to the following equation:

$\mathrm{HPI}=\frac{\sum_{i=1}^{n} W_{i} Q_{i}}{\sum_{i=1}^{n} W_{i}}$

where $Q_{i}=$ the sub-index of the $i$ th parameter, $W_{i}=$ the unit weight of the $i$ th parameter, and $n=$ the number of parameters which was considered in the calculation. $Q_{i}$ was calculated as below:

$Q_{i}=\sum_{i=1}^{n} \frac{\left|M_{i}-I_{i}\right|}{S_{i}-I_{i}} \times 100$

where $M_{i}=$ the monitored heavy metal, $I_{i}$ and $S_{i}=$ the ideal and standard values of the $i$ th parameter, respectively. The difference between $M_{i}$ and $I_{i}$ ignored the negative algebraic sign. The Ii values were taken from MAC values of the metals, and $S_{i}$ values were from the standard values set by DoE (1997).

\section{Statistical analyses and model development}

We used factor analysis on the physicochemical water parameters that could explain the relationships among numerous significant variables with a smaller set of independent variables (Gupta et al. 2005). For the current investigation, we used the principal component analysis as extraction method where correlation matrix and varimax rotation with Kaiser normalization had been done. Eigenvalues more than one were considered for analysis since a component with eigenvalues of less than one was considered as less significant, and such an observed variable could be ignored. We classified the estimated factor loadings as 'strong,' 'moderate,' and 'weak' corresponding to the absolute loading 
values of $>0.75,0.75-0.50$, and $0.50-0.30$, respectively, according to Liu et al. (2003).

Regression model had been developed to define the relationship between metals and water indices. Linear and nonlinear regression analyses were done to get the best-fitting model to establish such relations. Before developing the model, we checked the relationship between the predictive variables to avoid the collinearity between them by using Pearson correlation (Tabachnick and Fidell 2001). The significance level of the tests was set as $p$ value $<0.05$.

We established models in two different approaches. In approach 1 , we chose water quality indices as independent variables and metals as a dependent, and in approach 2 , vice versa. The best-fitted models had been established in three steps. At first step, we examined the independent (i.e., predictive) variables for the existence of significance relationship (i.e., collinearity). In the second step, the significant relation between metals and water indices was scrutinized to find which dependent variables (i.e., $\mathrm{Cr}, \mathrm{Cd}$, and $\mathrm{Pb}$ ) would have a significant relationship with the predictive variables (i.e., water indices selected from the first step). In the final step, best model had been selected based on the $p$ value, Akaike's corrected information criterion (AICc), AICc difference $\left(\Delta_{i}\right)$, and Akaike weights $\left(w_{i}\right)$. The same steps were followed for the approach 2 .

We used AICc instead of Akaike information criterion (AIC) since the sample size was small and the ratio between the number of observations to the number of parameters using the model was less than 40 (Burnham and Anderson 2004). Lower AICc value means better model among all models. The best model would have zero $\Delta_{i}$ value, whereas $w_{i}$ showed the probability of the model to be best (Burnham and Anderson 2004). We used the SPSS 16.0 for all statistical analyses as well as to develop and evaluate the models.

\section{Results and discussion}

\section{Physicochemical parameters}

$\mathrm{pH}$ values affect the biological and chemical reactions, and it is one of the most traditional measuring parameters for most water. The $\mathrm{pH}$ value of groundwater was between slightly acidic and alkaline (6.67 to 8.86 ) with the mean value of 8.07 (Table 1). We found the highest $\mathrm{pH}$ value in GW13 and GW18 sampling sites which were situated near a shipyard and food processing industry, respectively, and the lowest $\mathrm{pH}$ value in GW1 sampling site near a natural gas utilized electricity generating power plant (Fig. 1). According to WHO (1993) and DoE (1997), the standard pH value is 6.5 to 8.5 for drinking water which was violated by $15 \%$ samples. Depletion of DO in water supplies encourages the microbial reduction of nitrate to nitrite and sulfate to sulfide

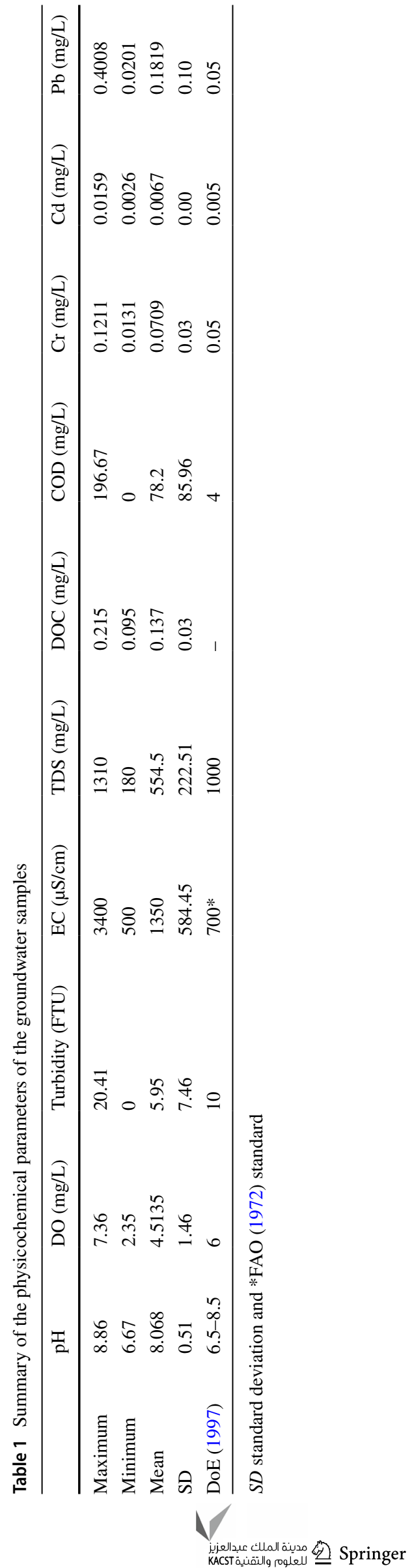


(WHO 1993). The highest DO value $(7.36 \mathrm{mg} / \mathrm{L})$ was found in GW4 sampling site near a cement industry, and the lowest DO value $(3.35 \mathrm{mg} / \mathrm{L})$ was found in GW6 sampling site near a paper mill that indicated possible microbial organic decomposition. DoE (1997) standard of DO is $6 \mathrm{mg} / \mathrm{L}$ for drinking water and 5 or more for irrigation where only $15 \%$ samples and 35\% samples satisfied the standards for drinking and irrigation water quality, respectively.

Total dissolved solids may affect the water quality adversely in many ways (APHA 1998). Here the variation of TDS was similar to EC. The highest $(1310 \mathrm{mg} / \mathrm{L})$ and the lowest $(180 \mathrm{mg} / \mathrm{L})$ TDS values were found in GW15 and GW4 sampling sites which were close to salt and cement industries, respectively (Fig. 1, Table 1). Only GW15 sample exceeded the standard for drinking water $(1000 \mathrm{mg} / \mathrm{L}$; DoE 1997) considering TDS. Electrical conductivity was a measure of indicating the total concentration of the ionized constituents of water, and it had a strong relation with $\operatorname{TDS}\left(r^{2}=0.98\right)$. Therefore, EC was found to be proportional to its dissolved mineral matters in water (Waghmare et al. 2012). In contaminated water, $\mathrm{EC}$ is also an indicator of the presence of excess ions. In the nonpolluting site of Bangladesh, EC value was lower than in the polluted site. For example, Molla et al. (2017) found EC ranges from 701 to $987 \mu \mathrm{S} / \mathrm{cm}$ with a mean of $603.2 \mu \mathrm{S} / \mathrm{cm}$ where the mean metal concentrations were low $(\mathrm{Pb}=0.0149, \mathrm{Cd}=0.0091$, As $=0.0026 \mathrm{mg} / \mathrm{L}$; except Cd, others were within DoE (1997) drinking water standard) in the western part of Bangladesh where the number of heavy industries was limited. Similar low EC value (range: $349-741 \mu \mathrm{S} / \mathrm{cm}$, mean: 563.07 $\mu \mathrm{S} / \mathrm{cm}$ ) was found by Rahman et al. (2017) in the similar part of Bangladesh, whereas groundwater of industry-rich area of this study had EC values ranging from 500 to $3400 \mu \mathrm{S} /$ $\mathrm{cm}$ with the mean of $1350 \mu \mathrm{S} / \mathrm{cm}$. The highest EC value of groundwater was found in GW15 sampling site which was situated close to the salt industry. The lowest EC value was found in GW4 sampling site as like as TDS value. Their trends also demonstrated that the ion concentrations were highest in the northeastern part of the study area (Fig. 2a, b).

Turbidity, an expression of the optical property, causes light to scatter and absorb rather than transmitted with no change in direction or flux level through the sample (APHA 1998). The mean turbidity value was 5.95 FTU where the highest value (20.41 FTU) (Table 1) was found in GW14 sampling site near a dockyard and the lowest $(0$ FTU) was in GW10 and GW15 (Fig. 1). The average value of the study area was below than DoE (1997) standard value of 10 FTU.

Chemical oxygen demand is the amount of a specified oxidant that reacts with the samples under controlled conditions (APHA 1998). It is one of the essential parameters for determining the quality of chemically oxidizing matter. Five randomly selected samples were taken for COD analysis.
The lowest COD value was found in sampling site GW16 which was collected from near an open area (Fig. 1). The permissible limit of COD is $4 \mathrm{mg} / \mathrm{L}$ (DoE 1997). Out of five, four samples had exceeded the limit. Organic matter contains thousands of components including macroscopic particles, colloids, and dissolved macromolecules (Sawyer et al. 1994). Dissolved organic carbon is a direct measurement of carbon contained in the organics in water (Findlay et al. 2010) which ranged from 0.095 to $0.215 \mathrm{mg} / \mathrm{L}$ with the mean value of $0.137 \mathrm{mg} / \mathrm{L}$ in this study (Table 1). Similar with COD trend, DO and DOC concentrations were lower in the south and southwestern area where the open area was located (Fig. 2c, d).

\section{Heavy metal analyses}

The summary of heavy metal concentrations in the groundwater is given in Table 1. Nickel was below the detection limit of the measuring instrument. Except $\mathrm{Ni}$, the order of mean heavy metal concentrations in the groundwater of the Meghna Ghat area was $\mathrm{Pb}>\mathrm{Cr}>\mathrm{Cd}$. From the spatial analysis, the metal concentrations were high on the northeastern side of the study area where most of the industries were located (Fig. 2e, f, g). The highest concentration of $\mathrm{Pb}(0.4008 \mathrm{mg} / \mathrm{L})$ was found in GW15 sampling site near the salt industry, whereas the lowest level $(0.0201 \mathrm{mg} / \mathrm{L})$ was located near a shipyard (Fig. 1). Eighty-five percentage samples did not satisfy the DoE (1997) drinking water standard $(0.05 \mathrm{mg} / \mathrm{L})$.

Although $\mathrm{Cr}$ is an essential nutrient required for sugar and fat metabolism in humans (Anderson and Kozlovsky 1985), high levels via inhalation, ingestion, or dermal contact might cause adverse health effects (Wilbur et al. 2012). We found the highest $\mathrm{Cr}(0.121 \mathrm{mg} / \mathrm{L})$ concentration in GW2 sampling site at the coal storage site and the lowest level $(0.0131 \mathrm{mg} / \mathrm{L})$ in GW3 sampling site near the shipyard. In our study, 75\% samples exceeded the DoE (1997) standard value $(0.05 \mathrm{mg} / \mathrm{L})$ for drinking water.

Unlike $\mathrm{Cr}, \mathrm{Cd}$ is a nonessential element for the crop plants and plants can take it very quickly when growing on $\mathrm{Cd}$ supplemented or Cd-contaminated soils, and thus $\mathrm{Cd}$ enters the food chain and causes damage to plant and human health (Nazar et al. 2012). Cadmium concentrations in our study exceeded the average abundance of the earth's groundwater (0.001-0.01 $\mu \mathrm{g} / \mathrm{L}$; APHA, 1998). The highest level of Cd $(0.016 \mathrm{mg} / \mathrm{L})$ was recorded in GW15 sampling site near the salt industry, and the lowest $(0.0026 \mathrm{mg} / \mathrm{L})$ was in $\mathrm{GW} 12$ near an industrial complex area. In the study area, 70\% samples exceeded the drinking water standard $(0.005 \mathrm{mg} / \mathrm{L})$ of DoE (1997).

People could consume water in two ways-direct intake as drinking water and indirect intake as food preparing water. In several regions of Bangladesh, the mean daily intake 
(a)

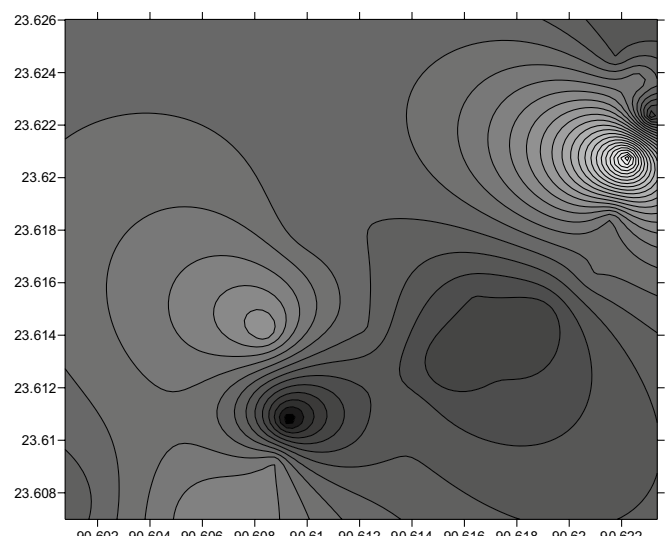

(c)

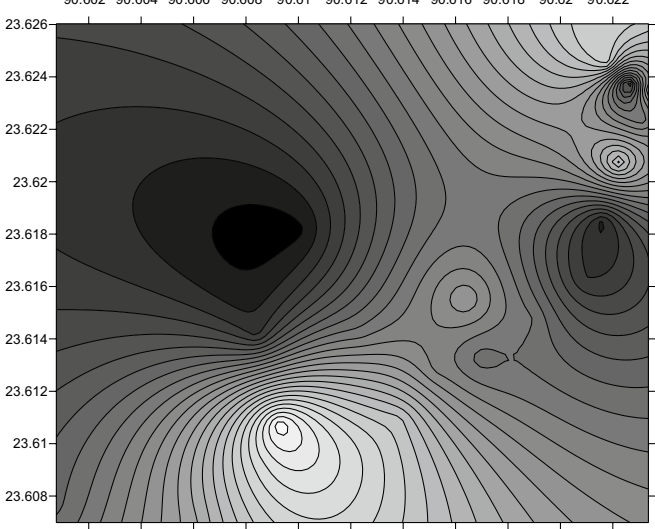

(e)

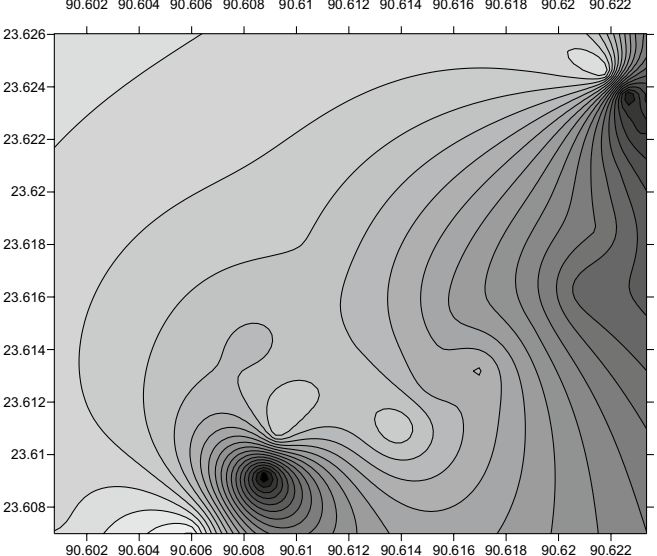

(g)

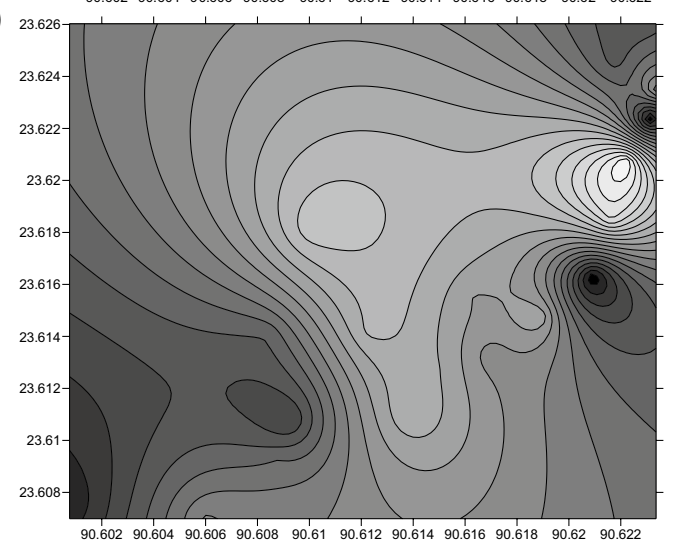

(b)

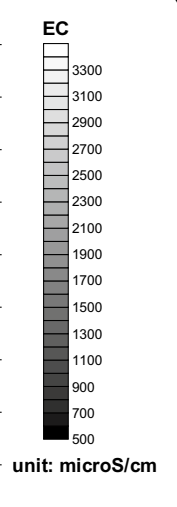

(d)
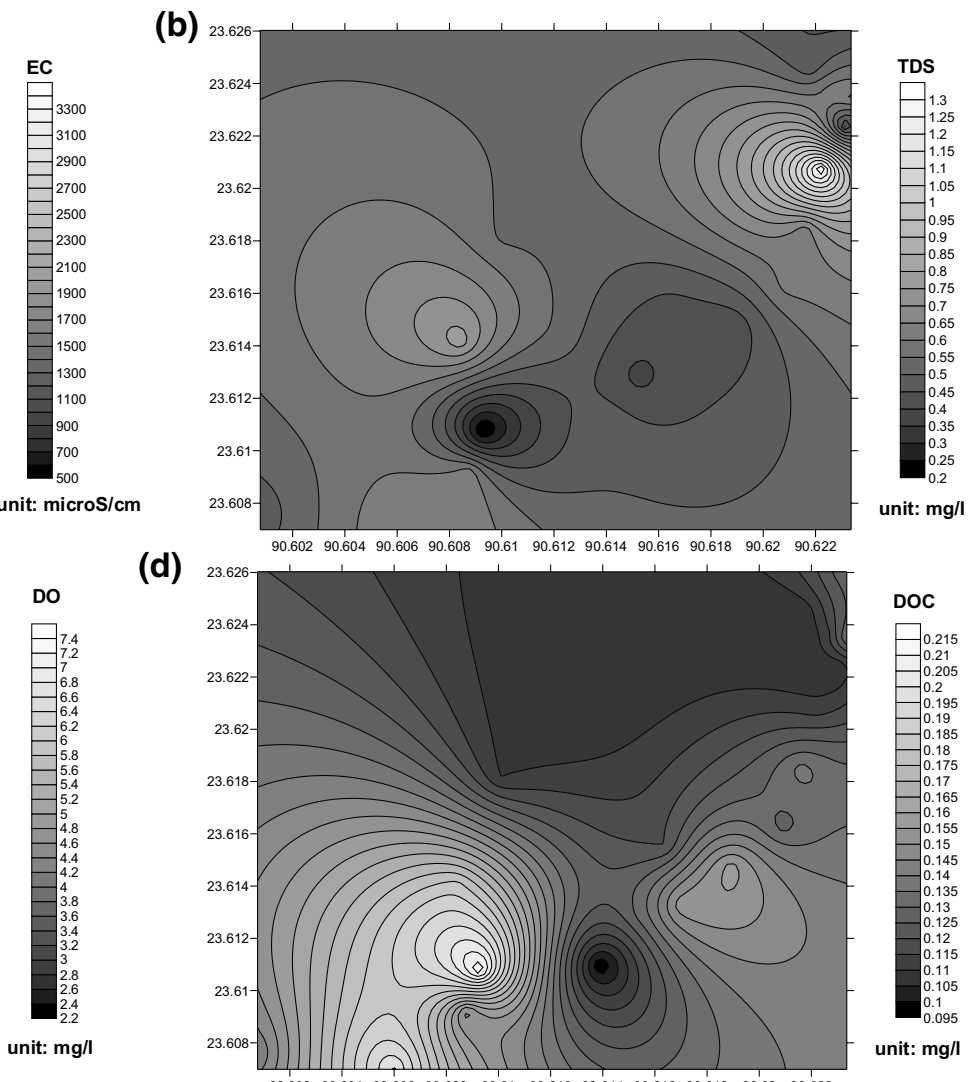

DOC

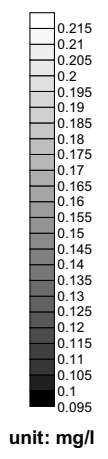

(f)

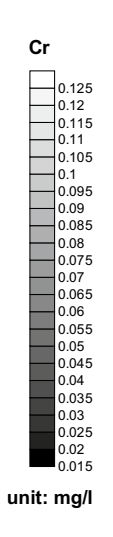

$\mathrm{Pb}$
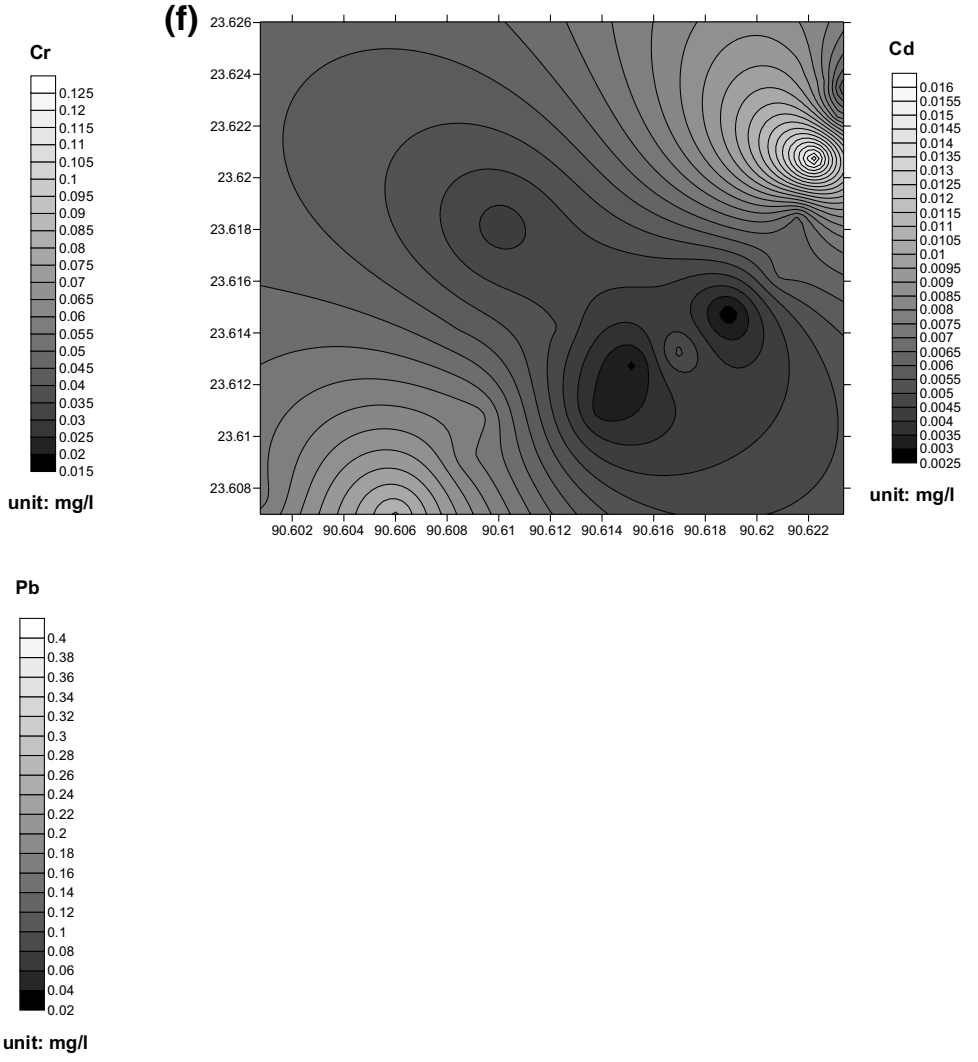

Fig. 2 Spatial distribution of EC (a), TDS (b), DO (c), DOC (d), $\mathrm{Cr}(\mathbf{e}), \mathrm{Cd}(\mathbf{f})$, and $\mathrm{Pb}(\mathbf{g})$. The contour maps were produced by using the Surfer (version 8) software 
including both direct and indirect intakes could be $4.6 \mathrm{~L}$ for male and 3.95 L for female (Watanabe et al. 2004). Based on this information, in our study area the daily intake of $\mathrm{Cr}$ could be $0.06-0.56$ (mean $\pm \mathrm{SD}=0.33 \pm 0.15$ ) $\mathrm{mg}$ for male and 0.05-0.48 (mean $\pm \mathrm{SD}=0.28 \pm 0.13) \mathrm{mg}$ for female, $\mathrm{Cd}$ could be $0.01-0.07$ (mean $\pm \mathrm{SD}=0.03 \pm 0.01$ ) $\mathrm{mg}$ for male and 0.01-0.06 (mean $\pm \mathrm{SD}=0.03 \pm 0.01) \mathrm{mg}$ for female, and $\mathrm{Pb}$ could be $0.09-1.84$ (mean $\pm \mathrm{SD}=0.84 \pm 0.48) \mathrm{mg}$ for male and $0.08-1.58$ (mean $\pm \mathrm{SD}=0.72 \pm 0.41) \mathrm{mg}$ for female. Although the amount of absorbed metal in the bodies depends on the personal nutrient status, immunological responses, age, gender, etc., our study revealed that people inhabiting in the study area could possess a high risk in metal exposure through the consumption of groundwater. For example, for Cr the daily safe intake is 0.05 to $0.2 \mathrm{mg}$ (NRC 1980). Considering daily intake of $\mathrm{Cr}$ through water, $80 \%$ male and $70 \%$ female might consume higher $\mathrm{Cr}$ than the recommended dose.

The study area was the part of the Bengal Basin which is the biggest fluvio-deltaic sedimentary system of the world (Mukherjee et al. 2009) and developed between 6 and 0.2kilo years ago (Allison et al. 2003). Geologically it is possible to have high metal concentrations in the groundwater. Faisal et al. (2014) mentioned that the source of heavy metals in the groundwater could be both anthropogenic and geogenic in the industrial area. However, in the adjacent studied region, Seddique et al. (2004) found that the metal concentrations in the groundwater were high in the dense industrial area rather than other parts of their studied area. Similarly, the occurrence of current high concentrations of heavy metals was concentrated in more industrialized area that might indicate a significant contribution from the industrial processes. However, the possible industrial processes that could be responsible for releasing of metals in the groundwater were not identified. Because in the study area there were many industries congesting in a small area whose information was not available.

\section{Factor analysis}

We detected three components whose eigenvalue was more than 1. Cumulative percentage of variance for the first three components of groundwater samples covered $70.03 \%$ (Fig. 3). The components 1, 2, and 3 explained 32.24, 24.81, and $12.98 \%$ of the variance, respectively. High loadings for $\mathrm{EC}$ and TDS in component 1 might indicate the presence of other chemicals which were not determined in the current experiment (Table 2). In lower $\mathrm{pH}$ and turbidity conditions, $\mathrm{DO}, \mathrm{DOC}$, and Cd increased in concentrations according to component 2. Cadmium showed moderate loadings in components 1 and 2, Cr demonstrated strong loadings in

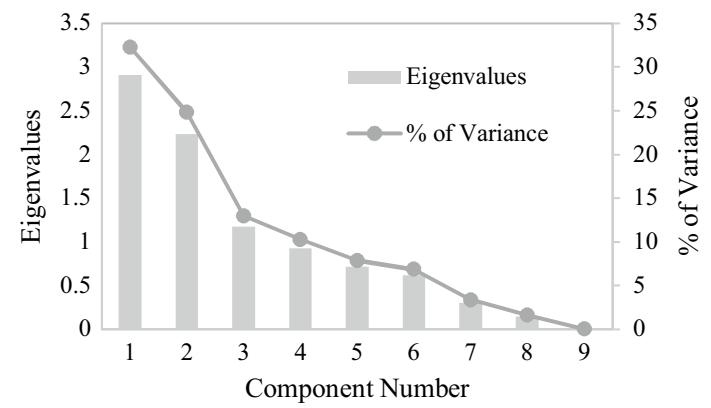

Fig. 3 Scree plot showing relationships between components and their corresponding percentage of variance along with eigenvalues

Table 2 Factor loadings for the groundwater samples

\begin{tabular}{lrrr}
\hline Parameters & \multicolumn{2}{l}{ Component } & \\
\cline { 2 - 4 } & \multicolumn{1}{l}{ 1 } & \multicolumn{1}{l}{3} \\
\hline pH & -0.040 & $\mathbf{- 0 . 7 3 2}$ & -0.292 \\
DO & 0.053 & $\mathbf{0 . 7 6 3}$ & 0.079 \\
Turbidity & -0.208 & -0.355 & $-\mathbf{0 . 5 9 9}$ \\
EC & $\mathbf{0 . 9 8 0}$ & -0.030 & 0.017 \\
TDS & $\mathbf{0 . 9 6 7}$ & -0.112 & -0.017 \\
DOC & -0.215 & 0.430 & 0.227 \\
Cr & -0.303 & 0.227 & $\mathbf{0 . 7 8 6}$ \\
Cd & $\mathbf{0 . 7 4 1}$ & $\mathbf{0 . 5 3 5}$ & -0.170 \\
Pb & $\mathbf{0 . 5 2 1}$ & -.469 & $\mathbf{0 . 5 0 1}$ \\
\hline
\end{tabular}

Bold loadings are strong, bold and italic loadings are moderate, and italic loadings are weak according to Liu et al. (2003)

component 3 and weak in component 1 , whereas $\mathrm{Pb}$ showed moderate loadings in components 1 and 3 and weak in component 2 . Therefore, the determined metals had mostly strong or moderate loadings in all components that might reveal the possibility to have a significant contribution to groundwater chemistry. The weak loadings of DOC in component 2 might indicate the probable metal binding or metal transformation with $\mathrm{Cd}$ and $\mathrm{Pb}$ in the study area.

\section{Water quality indices}

The determined Ni concentrations were estimated as zero by the detection instrument that means either there was no $\mathrm{Ni}$ present in the groundwater, or the levels of $\mathrm{Ni}$ were lower than the detection limit of the instrument. We used two different approaches to estimate the indices values. First, the zero concentrations of $\mathrm{Ni}$ had been used, and for the second approach $\mathrm{Ni}$ concentrations were assumed to be $0.001 \mathrm{mg} / \mathrm{L}$, which was the lowest detection limit of the determination method. We compared the results of the indices using 
Table 3 Comparison between two ways measured indices when they were estimated by assuming Ni concentration as zero and $0.001 \mathrm{mg} / \mathrm{L}$

\begin{tabular}{|c|c|c|c|c|c|c|c|c|c|c|c|c|}
\hline Sample ID & WQI* & WQI & $\operatorname{RE}(\%)$ & $\mathrm{DC}^{*}$ & DC & $\mathrm{RE}(\%)$ & HEI* & HEI & $\mathrm{RE}(\%)$ & HPI* & HPI & $\mathrm{RE}(\%)$ \\
\hline GW1 & 139.80 & 139.82 & 0.01 & 0.37 & 0.38 & 2.67 & 32.70 & 32.75 & 0.15 & 100.0049 & 100.0048 & $<0.001$ \\
\hline GW2 & 225.79 & 225.81 & 0.01 & 4.31 & 4.32 & 0.23 & 128.32 & 128.37 & 0.04 & 99.9897 & 99.9896 & $<0.001$ \\
\hline GW3 & 146.17 & 146.19 & 0.01 & 0.63 & 0.64 & 1.60 & 97.60 & 97.65 & 0.05 & 100.0040 & 100.0039 & $<0.001$ \\
\hline GW4 & 154.74 & 154.76 & 0.01 & 1.08 & 1.09 & 0.92 & 56.29 & 56.34 & 0.09 & 100.0019 & 100.0018 & $<0.001$ \\
\hline GW5 & 129.79 & 129.81 & 0.02 & 1.45 & 1.46 & 0.69 & 86.82 & 86.87 & 0.06 & 99.9988 & 99.9987 & $<0.001$ \\
\hline GW6 & 129.52 & 129.54 & 0.02 & 4.65 & 4.66 & 0.21 & 199.98 & 200.03 & 0.03 & 99.9823 & 99.9822 & $<0.001$ \\
\hline GW7 & 136.59 & 136.61 & 0.01 & 4.11 & 4.12 & 0.24 & 180.53 & 180.58 & 0.03 & 99.9855 & 99.9854 & $<0.001$ \\
\hline GW8 & 110.58 & 110.60 & 0.02 & 3.84 & 3.85 & 0.26 & 176.22 & 176.27 & 0.03 & 99.9853 & 99.9852 & $<0.001$ \\
\hline GW9 & 96.89 & 96.91 & 0.02 & 2.90 & 2.91 & 0.34 & 160.03 & 160.08 & 0.03 & 99.9894 & 99.9893 & $<0.001$ \\
\hline GW10 & 126.98 & 127.00 & 0.02 & 2.54 & 2.55 & 0.39 & 129.58 & 129.63 & 0.04 & 99.9930 & 99.9929 & $<0.001$ \\
\hline GW11 & 116.80 & 116.82 & 0.02 & 2.69 & 2.70 & 0.37 & 148.64 & 148.69 & 0.03 & 99.9916 & 99.9915 & $<0.001$ \\
\hline GW12 & 89.91 & 89.93 & 0.02 & 2.57 & 2.58 & 0.39 & 159.66 & 159.71 & 0.03 & 99.9907 & 99.9906 & $<0.001$ \\
\hline GW13 & 114.73 & 114.75 & 0.02 & -1.43 & -1.42 & -0.70 & 16.40 & 16.45 & 0.31 & 100.0124 & 100.0123 & $<0.001$ \\
\hline GW14 & 165.60 & 165.62 & 0.01 & 5.21 & 5.22 & 0.19 & 231.22 & 231.27 & 0.02 & 99.9815 & 99.9814 & $<0.001$ \\
\hline GW15 & 325.14 & 325.16 & 0.01 & 8.12 & 8.13 & 0.12 & 273.43 & 273.48 & 0.02 & 99.9759 & 99.9758 & $<0.001$ \\
\hline GW16 & 134.78 & 134.80 & 0.01 & -1.35 & -1.34 & -0.74 & 19.55 & 19.60 & 0.26 & 100.0134 & 100.0134 & $<0.001$ \\
\hline GW17 & 126.11 & 126.13 & 0.02 & 2.07 & 2.08 & 0.48 & 144.34 & 144.39 & 0.04 & 99.9954 & 99.9953 & $<0.001$ \\
\hline GW18 & 155.79 & 155.81 & 0.01 & 0.93 & 0.94 & 1.08 & 101.78 & 101.83 & 0.05 & 100.0030 & 100.0029 & $<0.001$ \\
\hline GW19 & 177.87 & 177.89 & 0.01 & 2.26 & 2.27 & 0.44 & 80.39 & 80.44 & 0.06 & 99.9974 & 99.9973 & $<0.001$ \\
\hline GW20 & 153.98 & 154.00 & 0.01 & 0.97 & 0.98 & 1.04 & 75.21 & 75.26 & 0.07 & 100.0026 & 100.0025 & $<0.001$ \\
\hline Mean & 147.88 & 147.90 & 0.01 & 2.40 & 2.41 & 0.42 & 124.93 & 124.98 & 0.04 & 99.9949 & 99.9948 & $<0.001$ \\
\hline
\end{tabular}

Indices with asterisks included $\mathrm{Ni}$ concentration as zero and without asterisks as $0.001 \mathrm{mg} / \mathrm{L}$. Relative errors (RE) between the indices with their individual values of water quality index (WQI), degree of contamination (DC), heavy metal evaluation index (HEI), and heavy metal pollution index (HPI) are shown

relative error that showed very small differences between the calculation of two approaches (Table 3 ). The mean relative errors of all indices were less than $0.5 \%$, which indicated that both approaches might be appropriated to use for the indices calculation.

Ranges of WQI, DC, HEI, and HPI, were 89.91 to 325.14, -1.43 to $8.12,16.40$ to 273.43 , and 99.98 to 100.01 , respectively considering the Ni concentrations as zero (Table 3). Water quality index provided a single value to indicate water quality of a source along with reducing the higher number of parameters into a simple expression resulting an easy interpretation of water quality monitoring data (Tyagi et al. 2013). Previous workers classified the water quality based on assigned ranges of the indices (Backman et al. 1998; Bhuiyan et al. 2010; Mohan et al. 1996; Tandel et al. 2011), and we classified our samples based on the previous classifications (Table 4). Considering WQI, GW15 sample was unsuitable for drinking and GW2 was classified as very poor-quality water, whereas $10 \%$ of the total samples were of good quality and $80 \%$ were classified as poor water.

For DC both low and high pollution levels were $30 \%$ of the total samples separately, and the rest $40 \%$ was within medium pollution level (Table 4). It is used as a reference for estimating the extent of metal pollution (Zou et al. 1988). Heavy metal evaluation index is used for straightforward interpretation of the pollution index and level of pollution (Edet and Offiong 2002; Prasanna et al. 2012). Bhuiyan et al. (2010) proposed HEI pollution-level classification of groundwater for Bangladesh. According to their classification, only $15 \%$ samples were low and medium levels of groundwater pollution separately, whereas the rest $70 \%$ samples displayed high pollution level (Table 4). Highest WQI (325.14), DC (8.12), and HEI (273.43) values were found in GW15. Besides the presence of the highest values of EC and TDS in GW15, the most elevated concentrations of $\mathrm{Cd}$ $(0.0159 \mathrm{mg} / \mathrm{L})$ and $\mathrm{Pb}(0.4008 \mathrm{mg} / \mathrm{L})$ caused the highest metal evaluation indices values in that site.

Areas with high levels of potentially harmful anthropogenic pollutants can be delineated by compiling maps of the indices (Backman et al. 1998). Water quality index, DC, and HEI demonstrated a similar pattern in the case of spatial distribution (Fig. 4). The major polluted area located at the northeastern side of the study area where most of the 


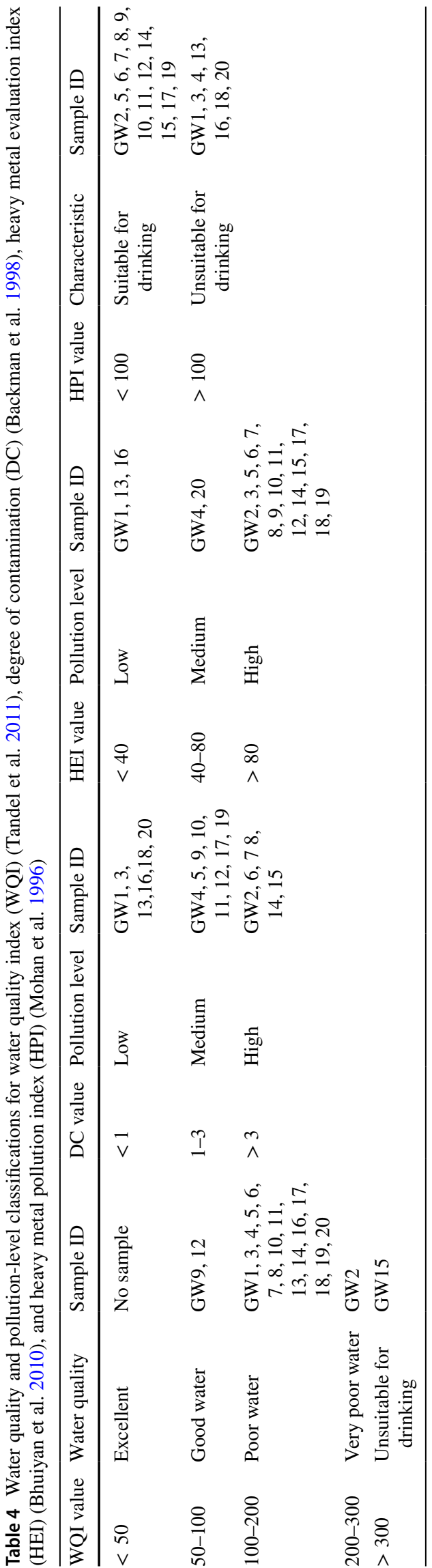

industries were situated. The lower level of pollution prevailed in the area where open spaces were located.

Recently, considerable attention had been given to HPI for evaluating heavy metal pollution in groundwater and surface water (Reddy 1995; Mohan et al. 1996). Heavy metal pollution index was calculated for the suitability of groundwater for human consumption concerning metal contamination (Balakrishnan and Ramu 2016). It is a powerful tool for ranking amalgamated influence of individual heavy metal on the overall water quality (Reza and Singh 2010) and for reviewing of the suitability of groundwater for human consumption (Rizwan et al. 2011). Permissible or critical pollution index for drinking water was proposed as 100 by Mohan et al. (1996). Thirty-five percent samples were unsuitable for drinking in the study area, and the rest were suitable as potable water (Table 4). However, considering HPI alone the samples with suitable potable water were very close to the critical value (i.e., 100) which disclosed the need of continuous monitoring for the future quality assurance.

The mean deviation could be used to find better quality of water in a specific area as done by Prasad and Bose (2001). Although they used the technique only for HPI, later this was also used for DC and HEI (e.g., Herojeet et al. 2015). In this study we used the technique for HPI, DC, HEI as well as for WQI. Sixty-five percentage, 50\%, 45\%, and 50\% samples were lower than the mean values of WQI (147.88), DC (2.40), HEI (124.93), and HPI (99.99), respectively, that showed negative and positive in percentages from the mean (Table 5). The negative mean deviation of the water samples represented better quality than other. However, by combining the results from Tables 4 and 5, we found a reduced number of better samples for drinking. In this approach the better quality of water was in GW1, 3, 5, 6, 7, 8, 9, 10, 11, 12, 13, 16, and GW17 considering WQI; GW1, 3, 4, 5, 13, 16, 17, 18, 19, and GW20 for DC; GW1, 4, 13, 16, and GW20 for HEI; and GW2, 6, 7, 8, 9, 10, 11, 12, 14 GW15 considering HPI. In our study, the values of $200,3,80$, and $<100$ could be used as boundary value for WQI, DC, HEI, and HPI, respectively. Based on the maximum similarity among the samples, the best quality of water might be present in the GW1, GW13, and GW16.

\section{Best-fitted models}

Although industrial development is necessary for economic growth, the pollution inhibition is essential (Cordero et al. 2005). For this reason, continuous monitoring with minimum water quality parameter is always welcome. We developed the models in three steps. In step 1, the correlation among the indices revealed that WQI significantly related 
(a)

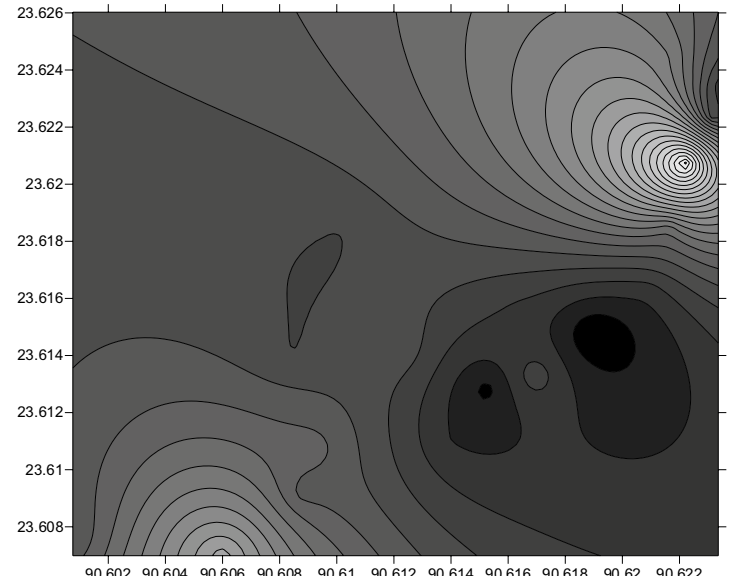

(c)

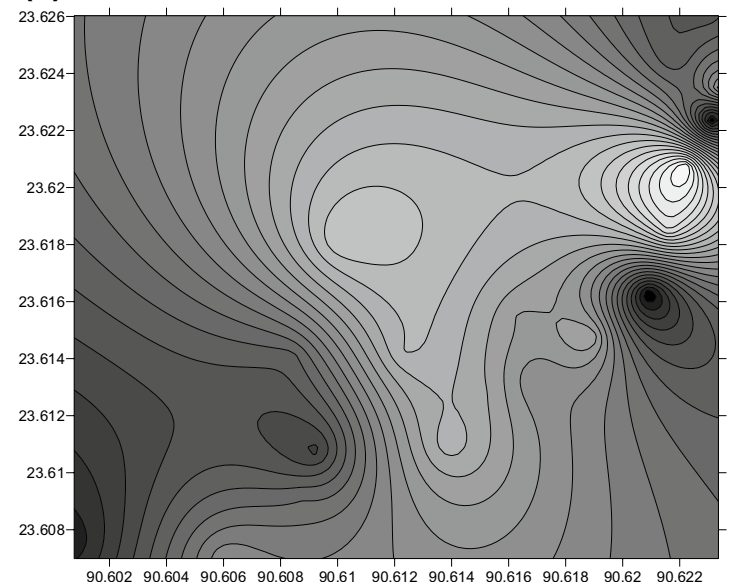

(b)
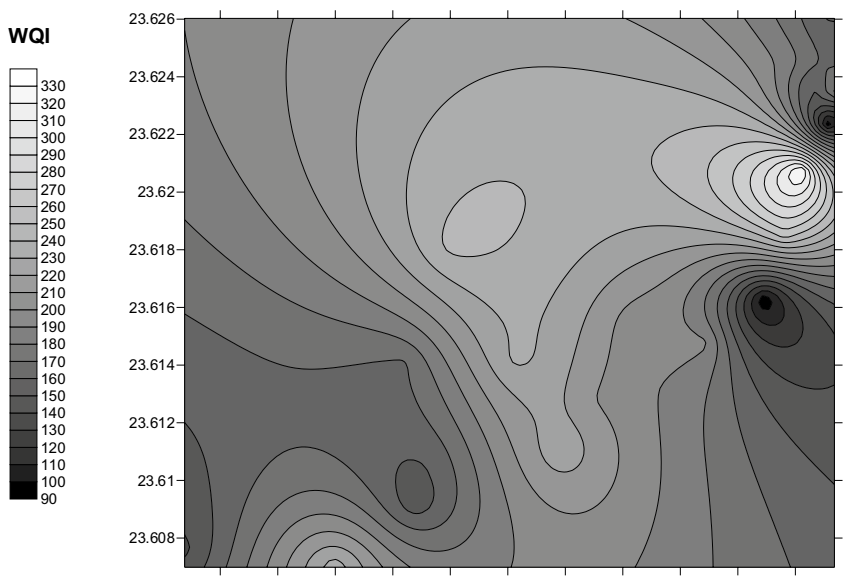

(d) $90.60290 .60490 .60690 .608 \quad 90.6190 .61290 .61490 .61690 .618 \quad 90.62 \quad 90.622$

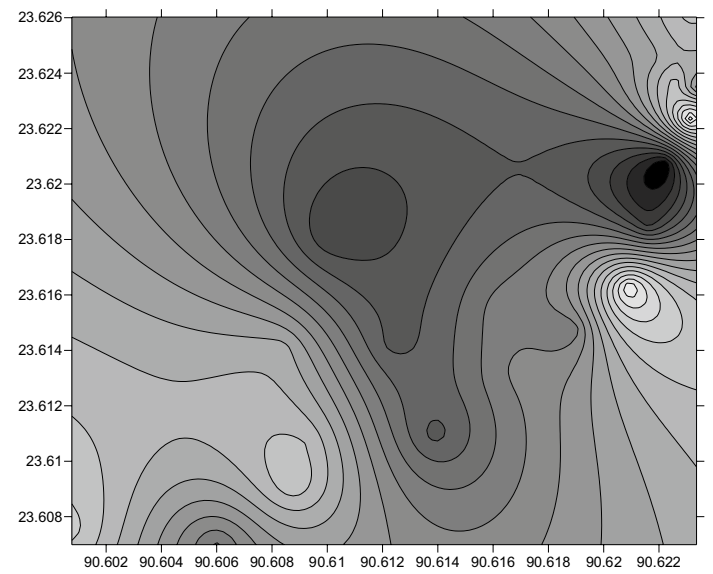

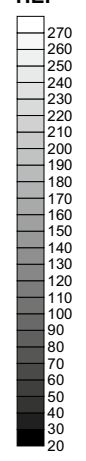

DC

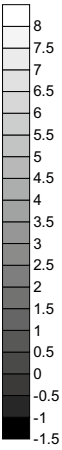

HPI

Fig. 4 Spatial distribution of water quality index (WQI) (a), degree of contamination (DC) (b), heavy metal evaluation index (HEI) (c) and heavy metal pollution index (HPI) (d). The contour maps were produced by using the Surfer (version 8) software

to only DC, whereas DC, HPI, and HEI significantly related to each other (Table 6). Therefore, either only WQI; HEI; HPI; or WQI with HEI or WQI with HPI could be used in the model that would avoid the collinearity between the predictive variables. In step 2, we estimated the relationships between metals and indices which are represented in Table 7. Chromium did not have a significant relationship with any of the water indices. Cadmium had a significant relationship with $\mathrm{WQI}$, and $\mathrm{Pb}$ had a significant relationship with DC, HEI, and HPI. In step 3, only Pb versus HEI and HPI versus $\mathrm{Pb}$ had been selected to be the best-fitted models (Table 8), whereas other models (not shown) were rejected due to either lack of significant level or high $\Delta_{i}$ values. By using these models, in the future we can estimate HEI or HPI from $\mathrm{Pb}$ for the study area that would save time and cost of laboratory experiment and would create less pollutants from laboratory and could be an easy way to continuously monitor the water quality.

\section{Conclusion}

The study area, the Meghna Ghat industrial area, located in an island. So, the area has high potentiality to be a model for monitoring and controlling the groundwater pollution originating from industrial processes. At present most of the groundwater samples showed a high level of metal concentrations that also reflected in the water quality indices. Seventy-five percentage, $70 \%$, and $85 \%$ of samples exceeded the standard values of Bangladesh for $\mathrm{Cr}, \mathrm{Cd}$, and $\mathrm{Pb}$, respectively. In the case of water quality indices, only $10 \%$ samples were good according to water quality index; $30 \%$ and $15 \%$ 
Table 5 Mean deviation (MD) and percentage of mean deviation (\% MD) for water quality index (WQI), degree of contamination (DC), heavy metal evaluation index (HEI), and heavy metal pollution index (HPI)

\begin{tabular}{|c|c|c|c|c|c|c|c|c|}
\hline \multirow[t]{2}{*}{ Sample ID } & \multicolumn{2}{|l|}{ WQI } & \multicolumn{2}{|l|}{ DC } & \multicolumn{2}{|l|}{ HEI } & \multicolumn{2}{|l|}{ HPI } \\
\hline & $\mathrm{MD}$ & $\%$ Deviation & MD & $\%$ Deviation & MD & $\%$ Deviation & MD & $\%$ Deviation \\
\hline GW1 & -0.40 & -5.78 & -0.101 & -540.72 & -0.0046 & -282.05 & 0.00050 & 0.0099 \\
\hline GW2 & 3.90 & 34.51 & 0.096 & 44.38 & 0.0002 & 2.64 & -0.00026 & -0.0052 \\
\hline GW3 & -0.09 & -1.17 & -0.089 & -282.80 & -0.0014 & -28.01 & 0.00045 & 0.0090 \\
\hline GW4 & 0.34 & 4.43 & -0.066 & -121.47 & -0.0034 & -121.95 & 0.00035 & 0.0070 \\
\hline GW5 & -0.90 & -13.94 & -0.047 & -65.49 & -0.0019 & -43.90 & 0.00019 & 0.0038 \\
\hline GW6 & -0.92 & -14.17 & 0.113 & 48.49 & 0.0038 & 37.53 & -0.00063 & -0.0127 \\
\hline GW7 & -0.56 & -8.26 & 0.085 & 41.64 & 0.0028 & 30.79 & -0.00047 & -0.0094 \\
\hline GW8 & -1.87 & -33.73 & 0.072 & 37.66 & 0.0026 & 29.10 & -0.00048 & -0.0096 \\
\hline GW9 & -2.55 & -52.62 & 0.025 & 17.43 & 0.0018 & 21.93 & -0.00028 & -0.0056 \\
\hline GW10 & -1.04 & -16.45 & 0.007 & 5.66 & 0.0002 & 3.59 & -0.00010 & -0.0019 \\
\hline GW11 & -1.55 & -26.60 & 0.015 & 11.05 & 0.0012 & 15.95 & -0.00017 & -0.0033 \\
\hline GW12 & -2.90 & -64.47 & 0.009 & 6.69 & 0.0017 & 21.75 & -0.00021 & -0.0043 \\
\hline GW13 & -1.66 & -28.90 & -0.191 & 268.04 & -0.0054 & -661.86 & 0.00087 & 0.0174 \\
\hline GW14 & 0.89 & 10.70 & 0.141 & 54.01 & 0.0053 & 45.97 & -0.00067 & -0.0134 \\
\hline GW15 & 8.86 & 54.52 & 0.286 & 70.50 & 0.0074 & 54.31 & -0.00095 & -0.0190 \\
\hline GW16 & -0.65 & -9.72 & -0.187 & 277.50 & -0.0053 & -539.16 & 0.00093 & 0.0185 \\
\hline GW17 & -1.09 & -17.26 & -0.016 & -15.76 & 0.0010 & 13.44 & 0.00002 & 0.0004 \\
\hline GW18 & 0.40 & 5.08 & -0.074 & -158.78 & -0.0012 & -22.75 & 0.00040 & 0.0081 \\
\hline GW19 & 1.50 & 16.86 & -0.007 & -5.94 & -0.0022 & -55.41 & 0.00012 & 0.0025 \\
\hline GW20 & 0.31 & 3.96 & -0.072 & -148.06 & -0.0025 & -66.11 & 0.00038 & 0.0077 \\
\hline
\end{tabular}

Table 6 Pearson's correlation matrix among water quality index (WQI), degree of contamination (DC), heavy metal evaluation index (HEI), and heavy metal pollution index (HPI)

\begin{tabular}{lllll}
\hline & WQI & DC & HPI & HEI \\
\hline WQI & 1 & & & \\
DC & $0.56^{*}$ & 1 & & \\
HPI & -0.34 & $-0.97^{* *}$ & 1 & \\
HEI & 0.35 & $0.94^{* *}$ & $-0.96^{* *}$ & 1 \\
\hline
\end{tabular}

*Correlation is significant at the 0.05 level (2-tailed)

**Correlation is significant at the 0.01 level (2-tailed) samples were categorized as low level of pollution considering degree of contamination and heavy metal evaluation index, respectively. However, we could not trace the origin or the specific route to transfer the metals to the groundwater. Despite having this limitation, as a large area scale we believe that our research was able to demonstrate in which part of the groundwater was the most and least polluted. In the highly polluted part, future study could trace which industrial process(es) would be responsible to create and release pollutants in the groundwater and control it through different remediation techniques. Further studies would also need to determine the metal exposure to plants, animals, and humans in that area to assess how far the metals already polluted the environment.
Table 7 Correlation between metals and water indices such as water quality index (WQI), degree of contamination (DC), heavy metal evaluation index (HEI), and heavy metal pollution index (HPI)

\begin{tabular}{|c|c|c|c|c|c|c|c|c|}
\hline \multirow[t]{2}{*}{ Metals } & \multicolumn{2}{|l|}{ WQI } & \multicolumn{2}{|l|}{ DC } & \multicolumn{2}{|l|}{ HEI } & \multicolumn{2}{|l|}{ HPI } \\
\hline & $r$ & $p$ value & $r$ & $p$ value & $r$ & $p$ value & $r$ & $p$ value \\
\hline $\mathrm{Cr}$ & -0.01 & 0.95 & 0.27 & 0.24 & 0.04 & 0.87 & -0.32 & 0.17 \\
\hline $\mathrm{Cd}$ & 0.94 & $<0.001$ & 0.26 & 0.28 & 0.04 & 0.88 & -0.01 & 0.96 \\
\hline $\mathrm{Pb}$ & 0.34 & 0.15 & 0.93 & $<0.001$ & 1.00 & $<0.001$ & -0.96 & $<0.001$ \\
\hline
\end{tabular}


Table 8 The proposed models between metals and water indices

\begin{tabular}{lllll}
\hline Model equation & $p$ value & AICc & $\begin{array}{l}\text { AICc } \\
\text { difference } \\
\left(\Delta_{i}\right)\end{array}$ & $\begin{array}{l}\text { Akaike } \\
\text { weights } \\
\left(w_{i}\right)\end{array}$ \\
\hline $\mathrm{Pb}=0.001+1.07 \ln (\mathrm{HEI})$ & $<0.001$ & -27.83 & 0 & 0.97 \\
$\mathrm{HPI}=99.989+\frac{0.001}{\mathrm{~Pb}}$ & $<0.001$ & -43.39 & 0 & 0.50 \\
\hline
\end{tabular}

Here, relationships between $\mathrm{Pb}$ and heavy metal evaluation index (HEI), and $\mathrm{Pb}$ and heavy metal pollution index (HPI) are shown

Open Access This article is licensed under a Creative Commons Attribution 4.0 International License, which permits use, sharing, adaptation, distribution and reproduction in any medium or format, as long as you give appropriate credit to the original author(s) and the source, provide a link to the Creative Commons licence, and indicate if changes were made. The images or other third party material in this article are included in the article's Creative Commons licence, unless indicated otherwise in a credit line to the material. If material is not included in the article's Creative Commons licence and your intended use is not permitted by statutory regulation or exceeds the permitted use, you will need to obtain permission directly from the copyright holder. To view a copy of this licence, visit http://creativecommons.org/licenses/by/4.0/.

\section{References}

Abtahi M, Golchinpour N, Yaghmaeian K, Rafiee M, Jahangirirad M, Keyani A, Saeedi R (2015) A modified drinking water quality index (DWQI) for assessing drinking source water quality in rural communities of Khuzestan Province, Iran. Eco Indi 53:283-291. https://doi.org/10.1016/j.ecolind.2015.02.009

Allison MA, Goodbred SL Jr, Kuehl SA, Khan SR (2003) Stratigraphic evolution of the late Holocene Ganges-Brahmaputra lower delta plain. Sedimen Geol 155(317-342):1. https://doi.org/10.1016/ S0037-0738(02)00185-9

Anderson RA, Kozlovsky AS (1985) Chromium intake, absorption and excretion of subjects consuming self-selected diets. Am J Clin Nutr 41:1177-1183

APHA (1998) Standard methods for the examination of water and wastewater. American Public Health Association, Washington, DC

Backman B, Bodis D, Lahermo P, Rapant S, Tarvainen T (1998) Application of a groundwater contamination index in Finland and Slovakia. Environ Geol 36:55-64. https://doi.org/10.1007/ s002540050320

Balakrishnan A, Ramu A (2016) Evaluation of heavy metal pollution index (HPI) of groundwater in and around the coastal area of Gulf of Mannar biosphere and Palk Strait. J Adv Chem Sci 2(3):331-333

Batabyal AK, Chakraborty S (2015) Hydrogeochemistry and water quality index in the assessment of groundwater quality for drinking uses. Water Environ Res 87(7):607-617

Begum A, HariKrishna S, Khan I (2009) Analysis of heavy metals in water, sediments and fish samples of Madivala Lakes of Bangalore, Karnataka. Int J Chem Technol Res 1(2):245-249

Bennett LE, Burkhead JL, Hale KL, Terry N, Pilon M, Pilon-Smits EAH (2003) Analysis of transgenic Indian Mustard plants for phytoremediation of metals-contaminated mine tailings. J Environ Qual 32:432-440. https://doi.org/10.2134/jeq2003.4320

BEZA (2017) Bangladesh Economic Zones Authority, Government of Bangladesh. http://www.beza.gov.bd/economic-zones-site/ private-sector-owned-sites/meghna-economic-zone-miez/. Accessed 21 Sept 2017

BGS and DPHE (2001) Arsenic contamination of groundwater in Bangladesh. Kinniburgh, DG and Smedley, PL (Editors). British Geological Survey Technical Report WC/00/19. British Geological Survey: Keyworth

Bhargava DS, Saxena BS, Dewakar RW (1998) A study of geopollutants in the Godavary river basin in India. Asian Environ 12:36-59

Bhuiyan MAH, Islam MA, Dampare SB, Parvez L, Suzuki S (2010) Evaluation of hazardous metal pollution in irrigation and drinking water systems in the vicinity of a coal mine area of northwestern Bangladesh. J Haz Mat 179:1065-1077. https://doi.org/10.1016/j. jhazmat.2010.03.114

BMD (2020) Bangladesh Meteorological Department, Dhaka, Bangladesh

Burnham KP, Anderson DR (2004) Multimodel inference: understanding AIC and BIC in model selection. Soc Meth Res 33:261-304. https://doi.org/10.1177/0049124104268644

Chen J, Huang Q, Lin Y, Fang Y, Qian H, Liu R, Ma H (2019) Hydrogeochemical characteristics and quality assessment of groundwater in an irrigated region, Northwest China. Water 11(1)

Cordero RR, Roth P, Silva LD (2005) Economic growth or environmental protection? The false dilemma of the Latin-American countries. Environ Sci Policy 8:392-398. https://doi.org/10.1016/j. envsci.2005.04.005

Das Kangabam R, Bhoominathan SD, Kanagaraj S, Govindaraju M (2017) Development of a water quality index (WQI) for the Loktak Lake in India. Appl Water Sci 7:2907-2918. https://doi. org/10.1007/s13201-017-0579-4

Dembitsky V (2003) Natural occurrence of arseno compounds in plants, lichens, fungi, algal species, and microorganism. Plant Sci 165:1177-1192. https://doi.org/10.1016/j.plantsci.2003.08.007

DoE (1997) The Environment Conservation Rules, 1997. The Department of Environment, Ministry of Environment and Forest, Government of the People's Republic of Bangladesh, Dhaka

Dwivedi S, Tiwari IC, Bhargava DS (1997) Water quality of the river Ganga at Varanasi. Institute of Engineers, Kolkota

Edet AE, Offiong OE (2002) Evaluation of water quality pollution indices for heavy metal contamination monitoring. A study case from Akpabuyo-Odukpani area, Lower Cross River Basin (southeastern Nigeria). Geo J 57:295-304. https://doi.org/10.1023/ B:GEJO.0000007250.92458.de

Etim EE, Akpan IU, Andrew C, Edet EJ (2012) Determination of water quality index of pipe borne water in Akwa Ibom State, Nigeria. Int J Chem Sci 5:179-182

Faisal BMR, Majumder RK, Uddin MJ, Halim MA (2014) Studies on heavy metals in industrial effluent, river and groundwater of Savar industrial area, Bangladesh by Principal Component Analysis. Int J Geomat Geosci 5:182-191

FAO (1972) Overall study of the messara plain. Report on study of the water resources and their exploitation for irrigation in eastern crete. FAO Report No. AGL:SF/GRE/31, Rome

Fernández N, Ramirez A, Solano F (2004) Physico-chemical water quality indices-a comparative review. Revista Bistua. https:// doi.org/10.24054/01204211.v1.n1.2004.9

Findlay S, McDowell WH, Fischer D, Pace ML, Caraco N, Kaushal SS, Weathers KC (2010) Total carbon analysis may overestimate organic carbon content of fresh waters in the presence of high dissolved inorganic carbon. Limnol Oceanogr Methods 8:196-201. https://doi.org/10.4319/lom.2010.8.196

Gao Y, Qian H, Ren W, Wang H, Liu F, Yang F (2020) Hydrogeochemical characterization and quality assessment of groundwater based on integrated-weight water quality index in a concentrated urban area. J Clean Prod. https://doi.org/10.1016/j.jclep ro. 2020.121006

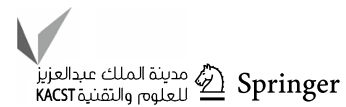


Gupta AK, Gupta SK, Patil RS (2005) Statistical analyses of coastal water quality for a port and harbour region in India. Environ Monit Assess 102:179-200. https://doi.org/10.1007/s10661-005-6021-7

Haque ME (2018) Study on surface water availability for future water demand for Dhaka city, Thesis for Doctor of Philosophy, Bangladesh University of Engineering and Technology, Dhaka, Bangladesh

Hassan M, Rahman MATMT, Saha B, Kamal AKI (2015) Status of heavy metals in water and sediment of the Meghna River, Bangladesh. Am J Environ Sci 11(6):427-439. https://doi.org/10.3844/ ajessp.2015.427.439

Herojeet R, Rishi MS, Kishore N (2015) Integrated approach of heavy metal pollution indices and complexity quantification using chemometric models in the Sirsa Basin, Nalagarh valley, Himachal Pradesh, India. Chin J Geochem 34(4):620-633. https://doi. org/10.1007/s11631-015-0075-1

Horton RK (1965) An index number system for rating water quality. J Water Pol Cont Feder 37(3):300-306

Ikhuoria EU, Okieimen FE (2000) Scavenging cadmium, copper, lead, nickel and zinc ions from aqueous solution by modified cellulosic sorbent. Int J Environ Stud 57(4):401-409. https://doi. org/10.1080/00207230008711284

ILA (2017) Lead uses-statistics. http://www.ila-lead.org/lead-facts/ lead-uses-statistics. Accessed 10 July 2017

Islam ARMT, Rakib MA, Islam MS, Jahan K, Patwary MA (2015) Assessment of health hazard of metal concentration in groundwater of Bangladesh. Am Chem Sci J 5(1):41-49

Khan SA, Uddin Z, Ihsanullah Zubair A (2011) Levels of selected heavy metals in drinking water of Peshawar City. Int J Sci Nat 2(3):648-652

Liu CW, Lin KH, Kuo YM (2003) Application of factor analysis in the assessment of groundwater quality in a blackfoot disease area in Taiwan. Sci Tot Environ 313:77-89. https://doi.org/10.1016/ S0048-9697(02)00683-6

Lunk HJ (2015) Discovery, properties and applications of chromium and its compounds. ChemTexts 1:6. https://doi.org/10.1007/s4082 8-015-0007-Z

Mohan SV, Nithila P, Reddy SJ (1996) Estimation of heavy metals in drinking water and development of heavy metal pollution index. J Environ Sci Health A Environ Sci Eng Toxicol Toxic/ Hazard Substances Environ Eng 31(2):283-289. https://doi. org/10.1080/10934529609376357

Molekoa M, Avtar R, Kumar P, Minh H, Kurniawan T (2019) Hydrogeochemical assessment of groundwater quality of Mokopane area, Limpopo, South Africa using statistical approach. Water 11(9):1891. https://doi.org/10.3390/w11091891

Molla MMA, Saha N, Salam SMA, Rakib-uz-Zaman M (2017) Surface and groundwater quality assessment based on multivariate statistical techniques in the vicinity of Mohanpur, Bangladesh. Int J Environ Health Eng 4:1-9. https://doi.org/10.4103/22779183.157717

Morgan JP, McIntire WG (1959) Quaternary geology of the Bengal Basin, East Pakistan and India. Bull Geol Soc Am 70:319-342

Mukherjee A, Fryar AE, Thomas WA (2009) Geologic, geomorphic and hydrologic framework and evolution of the Bengal basin, India and Bangladesh. J Asia Earth Sci 34:227-244. https://doi. org/10.1016/j.jseaes.2008.05.011

Nath BK, Chaliha C, Bhuyan B, Kalita E, Baruah DC, Bhagabati AK (2018) GIS mapping-based impact assessment of groundwater contamination by arsenic and other heavy metal contaminants in the Brahmaputra River valley: a water quality assessment study. J Clean Prod 201:1001-1011

Nazar R, Iqbal N, Masood A, Khan M, Syeed S, Khan N (2012) Cadmium toxicity in plants and role of mineral nutrients in its alleviation. Am J Plant Sci 3(10):1476-1489. https://doi.org/10.4236/ ajps. 2012.310178
NRC (1980) National research council. Recommended dietary allowances. National Academy of Sciences, Washington, DC

Nriagu JO (1992) Toxic metal pollution in Africa. Sci Total Environ 121:1-37. https://doi.org/10.1016/0048-9697(92)90304-B

Panakkal A, Kumar RBB (2014) Evaluation of the trace metal contamination in sediments of the urban water channels in Thrissur City, South India. Nat Environ Pollut Technol 13(4):701-706

Prasad B, Bose JM (2001) Evaluation of the heavy metal pollution index for surface and spring water near a limestone mining area of the lower Himalayas. Environ Geo 41:183-188. https://doi. org/10.1007/s002540100380

Prasanna MV, Praveena SM, Chidambaram S, Nagarajan R, Elayaraja A (2012) Evaluation of water quality pollution indices for heavy metal contamination monitoring: a case study from Curtin Lake, Miri City, East Malaysia. Environ Earth Sci 67:1987-2001. https ://doi.org/10.1007/s12665-012-1639-6

Quinn MJ, Sherlock JC (1990) The correspondence between U.K. 'action levels' for lead in blood and in water. Food Addit Contam 7:387-424. https://doi.org/10.1080/02652039009373904

Rahman MATMT, Majumder RK, Rahman SH, Halim MA (2011) Sources of deep groundwater salinity in the southwestern zone of Bangladesh. Environ Earth Sci 63:363-373. https://doi. org/10.1007/s12665-010-0707-z

Rahman MATMT, Saadat AHM, Islam MS, Al-Mansur MA, Ahmed S (2017) Groundwater characterization and selection of suitable water type for irrigation in the western region of Bangladesh. Appl Water Sci 7:233-243. https://doi.org/10.1007/s13201-014-0239-x

Reddy SJ (1995) Encyclopedia of environmental pollution and control, vol 1. Environmental Media, Karlia

Reza R, Singh G (2010) Assessment of groundwater quality status by using water quality index method in Orissa, India. World Appl Sci J 9(12):1392-1397

Rizwan R, Gurdeep S, Kumar JM (2011) Application of heavy metal pollution index for groundwater quality assessment in Angul District of Orissa, India. Int J Res Chem Environ 1(2):118-122

Sawyer CN, McCarty PL, Parkin GF (1994) Chemistry for environmental engineering, 4th edn. McGraw-Hill Inc., New York

Seddique AA, Ahmed KM, Shamsudduha M, Aziz Z, Hoque MA (2004) Heavy metal pollution in groundwater in and around Narayanganj town, Bangladesh. Bangla J Geol 23:1-12

Siegel FR (2002) Environmental geochemistry of potentially toxic metals. Springer, Berlin

Singh S, Lal S, Harjit J, Amlathe S, Kataria HC (2011) Potential of metal extractions in determination of trace metals in water sample. Adv Stud Bio 3(5):239-246

Tabachnick BG, Fidell LS (2001) Using multivariate statistics, 4th edn. Allyn and Bacon, Boston

Tandel BN, Macwan JEM, Soni CK (2011) Assessment of water quality index of small lake in south Gujarath region, India. Proceedings of ISEM-2011, Thailand

Tyagi S, Sharma B, Singh P, Dobhal R (2013) Water quality assessment in terms of water quality index. Am J Water Res 1(3):34-38. https ://doi.org/10.12691/ajwr-1-3-3

Vasanthavigar M, Srinivasamoorthy K, Vijayaragavan K, Ganthi RR, Chidambaram S, Anandhan P, Manivannan R, Vasudevan S (2010) Application of water quality index for groundwater quality assessment: Thirumanimuttar sub-basin, Tamilnadu, India. Environ Monit Assess 171(1-4):595-609

Waghmare NV, Shinde VD, Surve PR, Ambore NE (2012) Seasonal variations of physico-chemical characteristics of Jamgavan dam water of Hingoli District (M.S.) India. Int Multidiscip Res J 2(5):23-25

Watanabe C, Kawata A, Sudo N, Sekiyama M, Inaoka T, Bae M, Ohtsuka R (2004) Water intake in an Asian population living in arsenic-contaminated area. Toxicol Appl Pharmacol 198:272-282 
WHO (1993) Guidelines for drinking water quality. World Health Organization, Geneva

Wilbur S, Abadin H, Fay M, Yu D, Tencza MDB, Ingerman L, Klotzbach J, James S (2012) Toxicological profile for chromium. Agency for Toxic Substances and Disease Registry, Atlanta, USA. https://www. ncbi.nlm.nih.gov/books/NBK158851/. Accessed 12 March 2017

Wu Z, Zhang D, Cai Y, Wang X, Zhang L, Chen Y (2017) Water quality assessment based on the water quality index method in Lake Poyang: the largest freshwater lake in China. Sci Rep 7:17999. https://doi.org/10.1038/s41598-017-18285-y
Zou J, Zhang J, Wu J, Zhong F, Gu T (1988) On organic pollution and its control in the Haibe estuarine area of the Bohai Bay. Stud Mar Sin 29:1-20

Publisher's Note Springer Nature remains neutral with regard to jurisdictional claims in published maps and institutional affiliations. 